\title{
Yazılım Geliştirme Projelerinde Risk Yönetimi: Bir Banka ATM Projesi Örneği
}

\author{
Risk Management of Software Development Project: An Example of A Bank ATM Project
}

\author{
Harun Reşit YAZGAN', Pınar SÖNMEZ²
}

\begin{abstract}
ÖZET
Bu çalışmada, proje yönetiminin en önemli bileşenlerinden birisi olan risk yönetimi konusu incelenmiştir. Proje risk yönetiminde, risklerin analizi, tanımlanması, planlanması ve değerlendirme aşamaları ile birlikte, karşı plan oluşturulması maksadıyla izleme ve kontrol aşamalarının nasıl oluşturulabileceği konusu üzerinde durulacaktır. Bu aşamaların gerçekleştirilmesinde kişilere bağımlııktan kurtaracak belli karar mekanizmaları ve yöntemlerinin geliştirilmesine gerek duyulmaktadır. Bu maksatla, bankacılık sektöründeki bankamatiklerde kullanılan bir yazılımın geliştirilmesi projesi örnek olarak ele alınmıştır. Projedeki risk faktörlerinin belirlenmesi ve bunları önlenmeye yönelik politikaların nasıl belirlenebileceği bir örnek banka üzerinde gösterilmiştir.
\end{abstract}

Anahtar Kelimeler: Proje yönetimi, projelerde risk yönetimi, risk analizi, yazılım geliştirme projeleri

\section{GiRiş}

Günümüzde organizasyonlar varlıklarını oluşabilecek tehditlerden kaçınarak, fırsatları değerlendirerek ve bu fırsatların avantajlarını ortaya çıkararak sürdürmektedirler. Dolayısı ile yeni ve farklı şeyler ortaya koymak için projeler üstlenilir. Proje planlanırken ve yönetilirken yönetim seviyelerindeki kişilerin çeşitli konularda uygun ve doğru kararlar vermesi en önemli konular arasındadır. Bu kararların verilme aşamasında en ideal durum tam belirlilik durumudur. Yani tüm gerekli bilgiler bilinmekte ve bu bilgilere dayanarak güvenle karar verilebilecektir. Ancak gerçek hayatta tam belirlilik her zaman söz konusu olmayabilir ve sürekli fırsat oluşturabileceğimiz durumlar ile karşılaşmayabiliriz.

Bu belirsizlik ortamında oluşacak olayın gerçekleşme olasılığı ile olaydan etkilenme derecesi risk olarak adlandırılır. Bir amaç üzerinde olumlu etkisi olan belirsiz bir olay firsat olarak adlandırılırken, olumsuz sonuçlar tehdit olarak adlandırılır. Bu nedenle bazı risklerden kaçınılırken bazılarının oluşması için çaba gösterilir. İş yaşamında en sık karşılaşılan riskler; yetersiz zamanın ayrılmasından doğan zamansızlık ris$\mathrm{ki}$, maliyetin iyi hesaplanamamasından kaynaklanan

\begin{abstract}
In this study, risk management subject, which is one of important components of project management was studied. Firstly, analyzing, defining, planning and evaluation step of risks and then, observation and control that are necessary for the counterplan in the project management were examined. There is a need of certain decision mechanism and management policies, which are not biased on human in order to achieve these steps. For this purpose, a software development project that is required in the ATM was chosen as example. Determination of risk factors and their preventing policies were illustrated in a bank ATM software example.
\end{abstract}

Keywords: Project management, project risk management, risk analysis, software development project

yüksek maliyet riski, ürünün gereksinimleri karşılayamama riski, kullanılan yazılım ve donanım teknolojilerinden doğan riskler, projede yer alan insan riski, organizasyonun örgütsel yapısı ve yönetimi ile ilgili riskler, müşteri ihtiyaçlarının değişkenliğinden doğan riskler, tahmin edilen ama belirsizlik içeren ile tahmin edilemeyen ve kontrol edilemeyen çevresel etkenlerden oluşan riskler olmak üzere sıralanabilir.

Bir projeyi ele almak, yeni bir şeyler başarmak veya ortaya koymak belirsizlik ortamında ve zor rekabet şartları altında, gelişmiş teknoloji ve zor ekonomik koşullarla riske girmektir. Bu sebeple olumsuz sonuçlar doğurma potansiyeli olan proje risklerini belirlemek ve riskleri büyük ölçüde azaltmak maksadıyla değişik stratejiler geliştirilerek projelerde risk yönetimi yapılır Uzuntaş (2010), Emhan (2009).

Proje risk yönetimi tam belirlilik ile tam belirsizlik arasında bir yerde bulunmakta, işlerin kötü gitmesi olasılığını ve oluşabilecek risklerin yapacağı net etkinin düşürülmesini sağlamaya yönelik planlamayı ve uygulamayı içermektedir. Risk yönetiminin temel hedefi, belirsizlik kaynaklarını tanımlamak, belirsiz olayların ve koşulların nedenlerini tahmin etmek, tahmin edilen çıktıların ışığında çözüm stratejileri ortaya koy-

\footnotetext{
' Doç. Dr., Sakarya Üniversitesi, Mühendislik Fakültesi, Endüstri Mühendisliği Bölümü, yazgan@sakarya.edu.tr
}

${ }^{2}$ Sakarya Üniversitesi, Mühendislik Fakültesi, Endüstri Mühendisliği Bölümü, pnr.sonmez@gmail.com 
maktır Dikmen vd. (2008). Bunun yanı sıra, risk yönetimi sürecinde proje boyunca meydana gelebilecek fırsatların oluşma olasıığını arttııcı adımlar da aranır.

Projenin hedeflerine ulaşılıp başarılı olabilmesi için, planlanan proje ve onun yönetim alanları, özellikle bahsedilen risk yönetimi belli yöntem ve araçlarla yürütülebilmeli ve izlenip kontrol edilebilmelidir Uzzafer (2013), Anantatmula ve Fan (2013), Yacov (2009).

Kuruluşların, proje öncesi ve sonrası analiz ile risk yönetimi süreçlerinin ötesinde belirsizliğe karşı da yöntemler geliştirip kullanması projelerin hem planlama hem de yönetim kalitesine önemli ve olumlu katkıda bulunacaktır. Proje yönetimi sürecine karşı mevcut tehditlerin riskini düşürebilmek için kendi hedeflerini temel alarak, kendisine en uygun risk analizi yöntemini seçerken zaman ve para harcanacağı için, uygulamadaki mevcut risk analizi yöntemlerini karşılaştırıp değerlendirerek kendi ihtiyaçlarıyla örtüşen bir yöntemin seçilmesi kritiktir. Seçim için en iyi yol, bu yöntemlerin tarafsı ve nicel olarak karşılaştırılmasıdır Vorster, (2005), Ropponen ve Lyytinen(2000), Schmidt vd. (2001). En uygun risk analizi ve yönetimi seçimi için yapılan çalışmalar fazla sayıda değildir, dolayısıyla bu konu, yeni araştırmalara açıktır.

Risk analizi ve yönetimi için geliştirilen yöntemlerin en uygun olanının seçimi, etkin risk yönetimi için önemlidir. Risk analizi ve yönetimi için geliştirilmiş birçok yöntem bulunmakta, organizasyonlar bu yöntemlerden hangisini seçmeleri konusunda, objektif araçlara intiyaç duymaktadır. Bu nedenle, en uygun risk yönetim yöntemini seçmek için, organizasyona güven veren bir yaklaşım bulunmalıdır. Vorster ve Labuschagne (2005) mevcut risk analizi yöntemlerini karşılaştıran bir çalışma yapmışlardır. Bu yöntemlerin hepsinin uygulamada izledikleri yol ve kullandıkları metrikler farklılık gösterir. Sözgelimi, bazı risk analizi yöntemlerinde risk elemanının ölçümünde metrik olarak nitel veya nicel bir kısmında da nitel ve nicel özelliklerin beraberce kullanıldığı karma bir yapı gözlemlenmektedir. Başka bir açıdan, bazı risk analizleri uzun zamanlı ön çalıştırma gerektirirken, bazıları ise daha kalıplaşmış formlar uygulanarak kısa sürede sonuca varmayı sağlamaktadır Sönmez (2007).

Barry (1991) uydu yazılımlarının risklerinin belirlenmesinde on farklı risk unsurunu geliştirmiştir. Uygulamada projelerin başarısında kritik başarı faktörlerinin asla ihmal edilmemesi gerektiği üzerinde durmuştur. Barry ve DeMarco (1997) yazılım risklerinin belirlenmesi konusunda çalışma yapmışlardır. Yazılımdaki ölümcül (fatal) riskleri ve bunları organizasyonda doğuracağı sonuçları tartışmışlardır.
Kwak ve Stoddard (2004) yazılım risk yönetiminde mevcut risk anlayışı ve gelecekte oluşabilecek olanlar belirlenmesi üzerinde durmuşlardır. Özelikle Yazııım geliștirme projelerindeki riskleri belirlemişler ve etkili risk yönetiminin organizasyon kültürünün değişimi ile mümkün olabileceğini ifade etmişlerdir. Aynı zamanda yazılım geliştirme uygulamalarından çıkartılabilecek dersleri de çalışmalarında özetlemişlerdir. Bannerman (2008) çalışmalarında literatürdeki risk yönetimi konusunda çalışmaları inceleyerek yeniden değerlendirmişlerdir. Çalışmalarında riskin ortaya çıkışı ve yönetilmesi konusunda geliştirilen yöntemlerin pratik hayattaki uygulamaları konusunda literatürde önemli boşlukların olduğunu ifade etmişlerdir. Gündüz Ulusoy vd. (2012) çalışmalarında özelikle AR-Ge projelerinin proje sonrası safhası üzerinde durmuşlar ve proje yönetimi performansını etkileyen faktörlerin belirlenmesinde, geçmişte karşılaşılan risklerin saptanması ve bir risk listesi hazırlamak için analiz etmişlerdir. Proje risklerini ise; gecikmeler, beklenmeyen maliyetler veya tatmin etmeyen sonuçlar olarak tanımlamışlardır. Risk yönetimi, proje risklerini teşhis etme, analiz etme, karsı önlemleri alma ve izleme ve kontrolün sistematik surecidir. Erdem ve Younis (2014) yazılım projelerinin başarılı olmasında proje yönetimi kuramları ve risk kuramlarının belirlenmesi gerektiği üzerinde durmuşlardır. Proje yönetiminde risk yönetimi için üç aşamalı bir süreç belirlemişlerdir.

\section{RISK YÖNETIM SÜRECI}

Risk Yönetim sürecinde farklı adımlar önerilmiş olmasına rağmen genel kabul görmüş adımlar; planlama, risklerin belirlenmesi, analiz, risklere yanıt planı oluşturma, izlenmesi ve kontrolü şeklinde tanımlanabilir

Planlama aşamasında; risk yönetim faaliyetleri için gerekecek insan, zaman, para gibi kaynakların yeterliliğinin sağlanması planlanır. Riskleri tanımlamak için gerekecek risk ölçen teknikler, risk analizlerinde izlenecek metotlar, risk kontrol aşaması için kurulacak düzenekler ile dokümantasyonu kısacası bütün risk yönetim aktivitelerinin nasıl yürütüleceğine dair planlama bu aşamada yapılır. Bu hazırlık aşaması ve planlama süreci risk yönetiminde hata olasılıklarını azaltması, kazanç olasılıklarını da artırması beklenir.

Risklerin tanımlama sürecinde ise, projeyi etkilemesi muhtemel olan riskleri ve bu risklerin özelliklerinin tanımlandığı ve belgelendiği süreçtir. Riskleri tanımlamadaki izlenecek yol, proje ekibi üyelerinin, paydaşların veya riskler hakkında bilgi verebilecek kişilerin toplanıp proje belgelerini incelemeleri ardından projede karşılaşılabilecek bütün olası risklerin neler olabileceği hakkında bilgi paylaşımı toplantıları 
düzenlemektir. Bu süreç sonunda olası risk faktörleri, riskler, ana nedenleri, etkileri ve önlemleri tanımlanır ve risk listesi oluşturulur.

Risk analizi, herhangi bir sistemde tehlikelerden kaynaklanan risklerin büyüklüğünü tahmin etme ve mevcut kontrollerin yeterliliğini dikkate alarak bu risklerin kabul edilebilir olup olmadığına karar verme sürecidir. Risklere bu şekilde değer biçmek gereklidir çünkü bunlara çözüm bulmanın da bir gideri vardır ve sınırlı olan proje kaynaklarını da uygun bir şekilde kullanmak gerekmektedir.

Risk analiz edilirken belli ilkelere dikkat etmek gerekir Nakatsu ve lacovou (2009), Narayaswany ve Henry (2013). Risk analizi yapılırken olasılık ve etki değerleri belli aralıklarda küçükten büyüğe sıralanır, bu ister sayısal değerlerle olsun ister sözel ifadelerle olsun riskin gerçekleşme olasılığını ve etkisini ifade eder. Project Management Body of Knowledge (PMBOK) risklerin tehdit karlığına göre sıralamasının önemli olduğu vurgulanmış, nitel ve nicel analizlerin kullanılması önerilmiştir.

Risk yanıtlarının planlanması, proje hedeflerinin karşı karşıya olduğu tehditleri azaltmaya yönelik seçenekleri ve eylemleri geliştirme sürecidir. Süreç, üzerinde anlaşılan ve finanse edilen risk yanıtlarının her biri için, sorumluluk üstlenecek bir kişinin belirlenmesini ve atanmasını da içermektedir. Riskle mücadelede kullanılacak yaklaşım yönteminin ve her biri için kullanılacak tekniğin kararlaştırılması gerekmekte. Kullanılacak her bir tekniğin ortaya çıkarabileceği durumlar farklılık arz edebilecektir Drucker (1996).

Risklere yanıt verme stratejileri belirlenirken şu adımların izlenebilir;

- Kabul edilebilir başka alternatiflerin olup olmadığı, riskin proje hedeflerinden en az birini başarıp başarmadığı, riskin sonuçlarını hesaplamak için yeterli verinin olup olmadığı, riskin maliyete ve faaliyet çizelgesine getireceği yükün fazla olup olmadığı incelenmelidir.

- Risk önleme faaliyetleri ile net fayda analizlerinin yapılarak ve hangisinin uygun olabileceğine karar verilmesi yerinde olacaktır.

Eğer kabul edilebilir başka alternatifler var ise, işi yapmak için riskten kaçınıla bilineceği kabul edilebilir. Riskin projeye etkisini ve gerçekleşme olasılığını azaltmak için ek önleyici faaliyetler var ise risk hafifletilebilir. Riskin sorumluluğu alınmak istenmiyorsa transfer edilmesine veya paylaşılmasına onay verilebilir. Riskin sonuçlarının hesaplanmasında yeterli veri olmaması durumunda ise riskin kabul edilmesi, risk ve maliyetinin üstlenilmesi ve proje boyunca iz- lenmesi şartı konulabilir. Yüksek olasılıklı riskler ve paydaş toleransları dolayısı ile risk toleranslarındaki aşırı iyimserlik göz önüne alınarak -/+ \%10 oranında fon ayrılabilir. Risk maliyet unsurlarının yanı sıra risk zaman faaliyetlerinin de belirlenmesi uygun olacaktır.

Riskleri önlemek adına uygulanan risk yanıtlama planlarının işleyip işlemediği ve beklenen sonuçları verip vermediği izlenmelidir. Bunun amacı izleme ve denetim sürecinde risk sorumlularının kendilerine atanan riskler üzerinde meydana gelen değişikliklerin takip edilmesini; risk olasılığının projeye etkisinin arttığı veya azaldığı görülmek istenir ise, risk parametrelerinin yeniden değerlendirilmesi ve planlanmasında uygun değişikliklerin yapılmasına imkan tanınması yerinde olacaktır Verner ve Evanco (2005), McManus (2012).

Risk yönetim sürecinde son aşama olarak değerlendirme sürecini görüyoruz. Bu süreçte risk sürecinin değerlendirerek bir risk veri tabanı oluşturulmasıdır. Geriye dönüp bakıldığında bu bilgilerin bir başka benzeri proje ele alındığında ders niteliğinde olması beklenebilir. Daha iyi bir yönetim süreci, uygulaması ve nasıl geliştirileceği bu süreçte ilgilenilen konular arasındadır.

\section{METOT: PROJE RISK YÖNETIMI}

Bir projede riskleri yönetmek için izlenmesi gereken adımlar Şekil 1' deki gibidir. Risk yönetim planı hazırlanır, riskler tanımlanır, niteliksel ve niceliksel analizler yapılır, risk yanıtlama planı hazırlanır, riskler izlenir ve kontrol edilir.

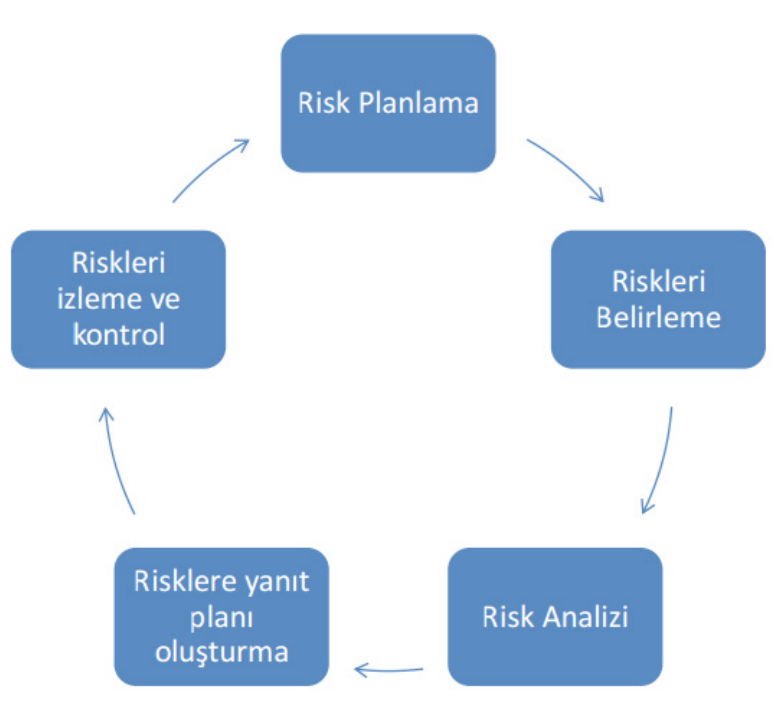

Şekil 1: Risk Yönetim Süreci 
Proje risk yönetiminde öncelikle proje yöneticisi, takım üyeleri, gerekli paydaşlar ve uzmanlar, kuruluşun çevresel etmenleri, örgütsel süreç yapısı, proje kapsam beyanı, proje yönetim planları, projenin ama$\mathrm{Cı}$, hedefleri, varsayımları, kısıtları, çıktıları ile çizelge ve bütçe özetini göz önüne alarak Risk Yönetim Planı oluşturulur. Bu süreçte, yönetim sürecinin nasıl işleyeceği planlanır.

Projeye özgü risk kategorileri uzman görüşleri dikkate alınarak belirlenir. Risk ekibi tarafından bilgi toplama tekniği kullanılarak olası riskler, ana nedenleri ve önlemleri planlanır. Risk yönetimi sürecindeki tüm rol ve sorumluluklar belirlenir. Proje yönetim ekibinden ve/veya risk planlama ve yürütme faaliyetlerinden sorumlu kişilerden bir grup belirlenerek, rol ve sorumlulukların kişilere atanması sağlanır. Risklerin projeye etkilerinin değerlendirileceği proje hedefleri belirlenir.

Risk yönetim planında bir riski kimlerle, hangi yöntemlerle, nasıl tanımlanacağı belirlenir. Belirlenen risklerin her biri için bir aksiyon almak mantıklı olmayacağı için riskler önceliklendirilir. Bu nedenle ilk önce nitel risk analizin yapılması daha uygundur. Bu analizde riskler kaynağına göre, sıklığına göre vs. sınıflandırılarak ve önceliklendirilerek sıralanır. Daha sonra bu risklerden önem derecesine göre yukarda olanlar nicel risk analizden geçer. Bu analizde riskler artık sayısal değerler ile ifade edilir.

\subsection{Nitel risk analizi}

Tanımlanmış risklerin gerçekleşme olasılığının ve etki gücünün matematiksel değerler ile değil, sözel mantıkla, uygulamayı yapan uzmanın tecrübelerine ve sezgilerine başvurularak değerlendirildiği süreçtir. Tahminî risk derecesi hesaplanırken ve ifade edilirken rakamsal değerler yerine yüksek, çok yüksek, çok acil gibi tanımlayıc değerler kullanılır. Bu tür yöntemlerde, değerlendirmeyi yapan uzmanın sezgi ve muhakeme kabiliyeti, yöntemin güvenirliliği açısından önemlidir. Bu nedenle, kritik öneme haiz sistemlerde sadece nitel yöntemlerle risk değerlendirmesi yapmak doğru değildir Ceylan ve Başhelvacı (2011)

Nitel risk analizi sürecinin girdilerini, risk yönetim planı, tanımlanmış riskler, proje statüsü, proje tipi, veri doğruluğu, Tablo 1 deki gibi risk olasılık değerleri ve etki değerleri ile varsayımlar oluştururken, çıktılarını genel risk derecelendirme ölçümleri, risk öncelik listesi, kapsamlı analiz ve yönetim için riskler listesi ile nitel risk analiz sonuçları oluşturur.

Risk olasılık ve etki değerlendirilmesi sonucunda olasılık ve etki gücü matrisi oluşturma, varsayımların detaylı analizi, veri doğruluk sıralaması gibi araç ve teknikler kullanılarak, projenin genel risk tehdit sıra- laması, risklerin eğilimleri ve önleme fikirlerini ortaya çıkarmak mümkündür Uzuntaş (2010).

Tablo 1: Nitel Risk Hesabında Kullanılan Olasılık Değerleri

\begin{tabular}{|l|c|}
\hline \multicolumn{1}{|c|}{ OLASıLıK } & $\begin{array}{c}\text { Olasılık } \\
\text { Değeri }\end{array}$ \\
\hline $\begin{array}{l}\text { Riskin gerçekleşme olasılığının çok küçük olması } \\
\text { (\%0-\%5) }\end{array}$ & 1 \\
\hline Riskin olma olasılığı olmamasından az (\%6-\%20) & 2 \\
\hline Riskin olma veya olmama olasılığı aynı (\%21-\%50) & 3 \\
\hline $\begin{array}{l}\text { Riskin olma olasılığı olmamasından fazla (\%51- } \\
\% 90)\end{array}$ & 4 \\
\hline Risk olma olasılığı neredeyse kesin (\%91-\%100) & 5 \\
\hline
\end{tabular}

Riskler etkilerine göre en temel olarak şöyle sınıflandırılabilir, bunlar projenin yapısına göre artabilir, değişebilir.

$\checkmark$ Kalite Riskleri: İstenen performans seviyesine ulaşamama riskleri, Tablo 2 'de örneklendirilmiştir.

$\checkmark$ Zaman Çizelgesi Riskleri: Görevleri zamanında tamamlayamama riskleri, Tablo 3'te örneklendirilmiştir.

$\checkmark$ Maliyet Riskleri: Projeyi tahsisli bütçe sınırları içinde tamamlayamama riskleri, Tablo 4'te örneklendirilmiştir.

$\checkmark$ Kapsam Riskleri: Kapsam değişikliği yada düzeltme ihtiyacı gösteren riskler.

Tablo 2: Nitel Risk Hesabında Kullanılan Kalite Etki Değerleri

\begin{tabular}{|l|c|}
\hline \multicolumn{1}{|c|}{ KALITE ETKISI } & Etki Değeri \\
\hline Kalite bozulması ancak fark edilebilir düzeyde & 1 \\
\hline $\begin{array}{l}\text { Kalite bozulması fark edilebilir düzeyde ancak } \\
\text { kabul edilebilir }\end{array}$ & 3 \\
\hline Projenin nihai çıktısı kullanılamaz durumda & 5 \\
\hline
\end{tabular}

Tablo 3: Nitel Risk Hesabında Kullanılan Çizelge Etki Değerleri

\begin{tabular}{|l|c|}
\hline \multicolumn{1}{|c|}{ çiZELGE ETKisi } & Etki Değeri \\
\hline Proje bütününde önemsiz çizelge kayması & 1 \\
\hline Proje bütününde çizelge kayması <\%10 & 2 \\
\hline Proje bütününde çizelge kayması $\% 10-\% 20$ & 3 \\
\hline Proje bütününde çizelge kayması $\% 21-\% 50$ & 4 \\
\hline Proje bütününde çizelge kayması > \%50 & 5 \\
\hline
\end{tabular}

Tablo 4: Nitel Risk Hesabında Kullanılan Maliyet Etki Değerleri

\begin{tabular}{|l|c|}
\hline Maliyet Etkisi & Etki Değeri \\
\hline Önemsiz maliyet artışı & 1 \\
\hline Maliyet artışı < \%5 & 2 \\
\hline Maliyet artışı $\% 5-\% 10$ & 3 \\
\hline Maliyet artışı \%11- \%20 & 4 \\
\hline Maliyet artışı > \%20 & 5 \\
\hline
\end{tabular}


Yukarıdaki olasılık ve etki değerlerinden risk derecesini hesaplamada aşağıdaki gibi hesaplanır.

Risk Derecesi $=$ Tehlikeli Bir Olayın Meydana Gelme Ihtimali * Tehlikenin Etkisi

Risklerin değerlendirilmesi için kullanılmak üzere proje esnasında risklerin gerçekleşme olasılıkları ve proje hedefleri üzerindeki etkilerini derecelendirebileceğimiz olasılık ve etki dağılım tabloları hazırlanır Tablo 5 ve Tablo 6.

Tablo 5: Risklerin Proje Hedefleri Üzerindeki Etki Aralıkları

\begin{tabular}{|l|c|c|c|c|c|}
\hline $\begin{array}{l}\text { Etki } \\
\text { Derecesi }\end{array}$ & $\begin{array}{c}\text { Çok } \\
\text { Küçük } 1\end{array}$ & Küçük 2 & Orta 3 & $\begin{array}{c}\text { Yüksek } \\
4\end{array}$ & $\begin{array}{c}\text { Çok } \\
\text { Yüksek } 5\end{array}$ \\
\hline $\begin{array}{l}\text { Süre } \\
\text { Aralığı }\end{array}$ & $\begin{array}{c}<=15 \\
\text { gün }\end{array}$ & $\begin{array}{c}15 \text { gün- } \\
20 \text { gün }\end{array}$ & $\begin{array}{c}20 \text { gün- } \\
25 \text { gün }\end{array}$ & $\begin{array}{c}25 \text { gün- } \\
30 \text { gün }\end{array}$ & 30 gün $<$ \\
\hline $\begin{array}{l}\text { Maliyet } \\
\text { Aralığı }\end{array}$ & $\begin{array}{c}<= \\
150 \$\end{array}$ & $\begin{array}{c}150- \\
500 \$\end{array}$ & $\begin{array}{c}500- \\
1000 \$\end{array}$ & $\begin{array}{c}1000- \\
3000 \$\end{array}$ & $3000 \$<$ \\
\hline
\end{tabular}

Tablo 6: Risklerin Proje Esnasında Gerçekleşme Olasılık Aralıkları

\begin{tabular}{|c|c|c|c|c|c|}
\hline $\begin{array}{c}\text { Olasılık } \\
\text { Derecesi }\end{array}$ & $\begin{array}{c}\text { Çok } \\
\text { Küçük 1 }\end{array}$ & Küçük 2 & Orta 3 & Yüksek 4 & $\begin{array}{c}\text { Çok } \\
\text { Yüksek 5 }\end{array}$ \\
\hline $\begin{array}{c}\text { Olasılık } \\
\text { Aralığı }\end{array}$ & $<=\% 10$ & $\begin{array}{c}\% 10- \\
\% 30\end{array}$ & $\begin{array}{c}\% 30 \\
-\% 50\end{array}$ & $\% 50-\% 70$ & $\% 70<$ \\
\hline
\end{tabular}

Risk olasılıkları ve etki derecelerinin çarpımı ile bulunacak risk derecesi belirlenir, bu formül ile oluşturulan risk değerlendirme matrisi Tablo 7'deki gibidir Ceylan ve Başhelvacı (2011).

Tablo 7: Risk Değerlendirme Matrisi

\begin{tabular}{|c|c|c|c|c|c|}
\hline & \multicolumn{5}{|c|}{ Risk Derecesi } \\
\hline Etki & $\begin{array}{c}\text { Çok } \\
\text { Ciddi }\end{array}$ & Ciddi & Orta & Hafif & Çok Hafif \\
\hline Olasılık & 5 & 4 & 3 & 2 & 1 \\
\hline Çok Yüksek & Yüksek & Yüksek & Yüksek & Orta & Düşük \\
\hline 5 & 25 & 20 & 15 & 10 & 5 \\
\hline Yüksek & Yüksek & Yüksek & Orta & Orta & Düşük \\
\hline 4 & 20 & 16 & 12 & 8 & 4 \\
\hline Orta & Yüksek & Orta & Orta & Düşük & Düşük \\
\hline 3 & 15 & 12 & 9 & 6 & 3 \\
\hline Küçük & Orta & Orta & Düşük & Düşük & Düşük \\
\hline 2 & 10 & 8 & 6 & 4 & 2 \\
\hline Çok Küçük & Düşük & Düşük & Düşük & Düşük & Düşük \\
\hline 1 & 5 & 4 & 3 & 2 & 1 \\
\hline
\end{tabular}

Yüksek risk derecesinde olan riskler için proje başlamadan önce risk yanıt verme stratejileri ve uygulaması planlanması uygun olacaktır. Riskin süreye ve maliyete olumsuz etkisinin yanı sıra ikincil riskler doğurması ihtimalinin de azaltılması hedeflenmektedir. Orta ve düşük risk derecesi altında sınıflandırılan riskler için proje başladıktan sonra risk sorumlusu tarafından izleneceği, gerektiğinde aynı yöntemler kul- lanılarak riske yanıt verme stratejilerinin belirlenmesi önemli olacaktır.

\subsection{Nicel risk analizi}

Tanımlanmış olan risklerin oluşma olasılıkları ve proje aktivitelerine olan etkilerini sayısal olarak ifade edip, bu değerlerin sayısal ve mantıksal metotlar ile işlenip, risk değerinin bulunduğu bir analiz yöntemidir. Bu sayısal yöntemler, olasılık ve güvenirlik teoremleri gibi basit teknikler olabileceği gibi, benzetim modelleri gibi karmaşık tekniklerde olabilir. Risk derecesi ise aşağıdaki gibi hesaplanır.

Risk Derecesi $=$ Tehlikeli Bir Olayın Meydana Gelme İhtimali * Tehlikenin Etkisi

Tehlikenin Etkisi = Maliyet, Süre, Kalite, Kapsam vb.

Genel olarak riskin nitel olarak tanımlanması sürecinden sonra bu analiz yapılır, çünkü nitel risk analizi çalışmasında riskler olasılık ve etki derecelerine göre önceliklendirilmiş olur. Nicel risk analizinde özellikle risk derecesi yüksek olan risklerin üzerinde durulur ve Duyarlılık Analizi, Karar Ağacı Analizi, Uzman görüşleri ve Monte Carlo simülasyonu gibi teknikler kullanılarak tehdit gücüne göre risklerin sıralaması yapılır, proje için tahmini tamamlanma süresi ve maliyeti veya hedeflenen proje süresinin ve bütçesinin tutma olasılığı gibi değerler elde edilir ve sonucunda güncellenmiş risk listesi elde edilir Sönmez (2007). Projenin hedef süresi ve bütçesi güncellenir. Aynı zamanda bütçe ve toplam süre için ek ne kadar kaynağın yedeğe ayrılması gerektiği değerlendirilir.

\section{UYGULAMA: BANKACILIK SEKTÖRÜNDE YAZILIM GELIŞTIRME PROJESININ RISK YÖNETIMI}

\subsection{Yazılım Geliştirme Proje}

$\mathrm{Bu}$ çalışmanın amacı, müşteri tarafından belirlenen gereksinimlere göre $X$ bankasının ATM ağının kapsadığı hem banka sunucusunun hem de ATM makinelerinin yazilım gereksinimlerini analiz etmek, tasarlamak, uygulamak ve bakımını yapmaktır. Projenin amacı ile ilgili tüm faaliyetler doğrudan kapsam içinde sayılır. Projenin hedefleri aşağıdaki gibi belirlenmiştir:

Projenin teslim tarihine kadar projeyi tamamlamak, tüm çıktıları sağlamak

> Projeyi bütçesini aşmadan tamamlamak

> Yazılım ürününün tüm ihtiyaçlarını karşılamak

Varsayımlar:

$\checkmark$ ATM bilgisayar ağı ayrı bir projede yönetilmesi, her ATM ve merkez bankası arasında kabul edilebilirlik testi için tam zamanında mevcut olması 
$\checkmark$ Ele alınan proje daha geniş kapsamlı bir projenin parçası olmakla birlikte, bu çalışmada sadece yazılım kısmı dikkate alınmış ve ATM'nin donanım projesi hariç tutulmuştur. Projenin test aşamasında donanımın hazır olduğu kabulü vardır.

Bu proje bir firma-düzeltme-değeri olarak kabul edilmiş ve projenin belirlenen bütçeyi geçmemesi istenmektedir.

$\checkmark$ Projenin başarı oranı tahminleri +- $\% 10$ arasında olduğu kabul edilmiştir.

Proje aşağıdaki kısıtlarla planlanmıştır:

$\checkmark$ Bütçe: 1,600,000 TL (planlanan bütçenin \%10 'u olan risk faaliyet fonu + ek risk maliyeti + bakım maliyeti)

$\checkmark$ Süre: Bir yıl. Yazııım ürünü, ATM makinelerine kurulduğunda, ATM makinelerinin fiziksel olarak kalıcı lokasyonlarına yerleştirilmesi 30 gün süreceği düşünülmektedir.

$\checkmark$ Personel: Projenin gereksinim ve detay tasarım kısmında yardımcı olmak için firma dışından iki danışmana ihtiyaç duyulacaktır.

$\checkmark$ Bakım: Yazılım bakım maliyetlerinin yıllık 100,000 TL aşmaması istenmektedir.

Projenin beklenen çıktıları şunlar olacaktır:

$\checkmark$ Yazılım dokümantasyonları (kurulum, son kullanıc ve merkez bankasına uygulanan güncellemeler).

Proje dokümantasyonu (yazılım gereksinimleri ve yazılım tasarım beyannameleri).

$\checkmark$ Yazılım proje yönetimi planı (test, kalite güvence, yapılandırma, doğrulama ve onaylama planları)

$\checkmark$ Kullanıcılara uygulanan yazılım eğitimi (ATM kullanıcıları kurucuları ve yazııım bakım ekibi)

Yazılım programı, yazılım kütüphanesi ve donanı üzerindeki kurulumu

Projenin planlanan çizelge ve özeti:

> Projenin planlanan teslim tarihi: 1 Mayıs 2013

$>$ İşlem için yazılım ürünlerinin hazır olma tarihi: 29 Ocak 2014

Projenin bütçesi 1,600,000 TL. Yazılım ürünü teslim edildiğinde, yıllık bakım maliyeti 100,000 TL den fazla olmaması şeklinde özetlenebilir.

Proje yönetim planı:

İşi oluşturan faaliyetler, aralarındaki öncelik ilişkileri, bağlantıları yapılmış faaliyetlerin tespit edilen süreleri bir proje yazılım programı üzerinden kaydedilir. Bu faaliyetlerin kimler tarafından yapılaca- ğı belirlenir. Kaynakların faaliyetlere atamaları gerçekleştirilir. Çalışma takvimlerine göre kaynakların seviyelendirme işlemleri yapılır. Fazla yüklenmiş kaynaklar dengelenir. Bunun sonucunda her bir faaliyetin başlangıç ve bitiş tarihleri ortaya çıkar. Tüm bunlara istinaden projenin hangi gün teslim edileceği öngörülür. Projede ihtiyaç duyulan çalışanların, miktarları ve faaliyet alanları Tablo 8' de gösterilir.

Tablo 8: Projeye Atanan İnsan Kaynağının Detayları

\begin{tabular}{|c|c|c|}
\hline İnsan Kaynağı Tipi & Projede Yer Alacağı Kısım & Miktar \\
\hline Proje Müdürü & Her Alanda & 1 \\
\hline İhtiyaç Analisti -Lider & İhtiyaçlar & 1 \\
\hline İhtiyaç Analisti & İhtiyaçlar & 1 \\
\hline Danışman & İhtiyaçlar, Tasarım & 2 \\
\hline Yazılım Mimarı-Lider & Sistem Tahsisi & 1 \\
\hline Yazılım Mimarı & Sistem Tahsisi, Tasarım & 1 \\
\hline Programci-Lider & Uygulama & 1 \\
\hline Programcı & Uygulama & 1 \\
\hline $\begin{array}{l}\text { Doğrulama Mühendisi- } \\
\text { Lider }\end{array}$ & $\begin{array}{l}\text { İhtiyaçlar, Tasarım, } \\
\text { Uygulama }\end{array}$ & 1 \\
\hline Doğrulama Mühendisi & $\begin{array}{l}\text { İhtiyaçlar, Tasarım, } \\
\text { Uygulama }\end{array}$ & 1 \\
\hline Yazılım Mühendisi & Tasarım & 1 \\
\hline Onaylama Mühendisi & İhtiyaçlar, Tasarım & 1 \\
\hline Kalite Analisti & Her Alanda & 1 \\
\hline Yapılandırma Mühendisi & Her Alanda & 1 \\
\hline Veri tabanı Mühendisi & $\begin{array}{l}\text { İhtiyaçlar, Tasarım, } \\
\text { Kurulum }\end{array}$ & 1 \\
\hline Teknik Yazıcı & Belgelendirme & 1 \\
\hline Eğitim Uzmanı & Eğitim & 1 \\
\hline Kurulum Uzmanı & Kurulum & 1 \\
\hline
\end{tabular}

Proje için gerekli olan malzemelerin listesi Tablo 9 gibi belirlenmiştir.

Tablo 9: Projeye Atanan Malzeme Kaynağının Detayları

\begin{tabular}{|l|l|l|}
\hline \multicolumn{1}{|c|}{ Malzemeler } & \multicolumn{1}{c|}{ Birim } & \multicolumn{1}{c|}{ Maliyet } \\
\hline Çıktı Hizmetleri & $12 \mathrm{sa}$ & $250 \mathrm{TL} / \mathrm{sa}$ \\
\hline Bilgisayar Kullanımı & $20 \mathrm{sa}$ & $400 \mathrm{TL} / \mathrm{sa}$ \\
\hline Bilgisayar Yazııımı & 30 puan & $400 \mathrm{TL} / \mathrm{puan}$ \\
\hline Yazılım Deposu & $48 \mathrm{~GB} / \mathrm{ay}$ & $400 \mathrm{TL} / \mathrm{GB}$ \\
\hline
\end{tabular}

Proje sürecinin toplam süresi, başlangıç ve bitiş tarihleri, her bir temel görevin maliyetleri aşağıdaki Tablo $10^{\prime}$ da görülmektedir. 
Tablo 10: X Bank ATM Proje Özeti

\begin{tabular}{|c|c|c|c|c|}
\hline Proje Ana Aktiviteleri & Süre (gün) & Başlangıç Tarihi & Bitiş Tarihi & Maliyet (TL) \\
\hline X Bank ATM Projesi & 255.48 gün & $2 / 4 / 13$ & $25 / 3 / 14$ & $1,448,473.80$ \\
\hline Yazılım yaşam döngüsü model süreci & 2 & $2 / 4 / 13$ & $3 / 4 / 13$ & $1,000.00$ \\
\hline Projenin başlatılması & 44 & $2 / 4 / 13$ & $31 / 5 / 13$ & $104,492.00$ \\
\hline Proje izleme ve kontrol & 255.48 & $2 / 4 / 13$ & $25 / 3 / 14$ & $244,800.00$ \\
\hline Yapılandırma yönetimi & 35 & $31 / 5 / 13$ & $18 / 7 / 13$ & $33,900.00$ \\
\hline Yazılım kalite yönetimi & 79.33 & $31 / 5 / 13$ & $19 / 9 / 13$ & $55,598.40$ \\
\hline Sistem tahsisi & 10 & $31 / 5 / 13$ & $13 / 6 / 13$ & $24,000.00$ \\
\hline Gereksinimler & 70.17 & $2 / 4 / 13$ & $9 / 7 / 13$ & $148,470.00$ \\
\hline Tasarım & 132.4 & $2 / 4 / 13$ & $3 / 10 / 13$ & $329,500.00$ \\
\hline Doğrulama ve onaylama & 188.57 & $2 / 4 / 13$ & $20 / 12 / 13$ & $193,711.60$ \\
\hline Dokümantasyon gelişimi & 127.17 & $2 / 4 / 13$ & $26 / 9 / 13$ & $55,044.80$ \\
\hline Eğitim & 212.14 & $2 / 4 / 13$ & $23 / 1 / 14$ & $36,060.00$ \\
\hline Uygulama & 102.4 & $1 / 8 / 13$ & $23 / 12 / 13$ & $205,880.00$ \\
\hline Kurulum & 131.9 & $1 / 8 / 13$ & $3 / 2 / 14$ & $16,017.00$ \\
\hline İşleyiş ve Destek & 2 & $3 / 2 / 14$ & $5 / 2 / 14$ & 0.00 \\
\hline Bakım & 1 & $4 / 2 / 14$ & $5 / 2 / 14$ & 0.00 \\
\hline
\end{tabular}

\subsection{Projenin Risklerinin Belirlenmesi}

Risk yönetim ekibi projenin planlama aşamasında, maliyet ve zaman çizelgesi tahminleri, üretim ve hizmetler gözden geçirilmiş ve proje yönetim planında belirlenmiş projenin riskleri bilgi toplama tekniği olan Delphi tekniği kullanılarak yapılmıştır. Riskleri tanımlamada kolaylık sağlamak için planlama aşamasında misyon ve vizyon, organizasyon ve yönetim, müşteri, finansal ve ekonomik, teknik, kapsam ve personel olarak risk kategorileri belirlenmiştir. Delphi tekniği kullanılarak risk tanımlama aşaması şu şekilde gerçekleşmiştir:

1- Risk yönetim ekibinden olası risklerin tanımlanması istenmiş,

2- Alınan yanıtlar risk kategorilerine göre gruplanarak, risk yönetim ekibine yorumlanmaları üzerine tekrar gönderilmiş
3- Böylece risklerin ana nedenleri ve riskleri önleme çalışmaları belirlenmiş

4- Geriye yapılan dönüşler tekrar gözden geçirilerek, risk listesi sonuçlanmıştır.

Tablo 11 de olası tehditler, nedenleri ve önlemleri kendi risk kategorileri altında açıklanmıştır. Risk belirlemesi sürecinde görüşülen risklerin kök nedenleri, potansiyel tepkilerin daha sonraki aşama olan riske tepkinin planlanması aşamasına girdi olarak kullanılmıştır. Tanımlanan risklerin gerçekleşme olasılıklarına ve projeye etkilerine göre değerlendirilmesinde öncelikle nitel risk analizi yapılmıştır. Bu analizde, risklerin süreye ve maliyete etkileri sözel ifadeler ile dile getirilmiştir. Sözel ifadeler puanlandırılarak risklerin dereceleri bulunmuş ve değerlendirme sonucunda hangi risklerin ne boyutta önemli olduğu sözel olarak ifade edilmiştir. 


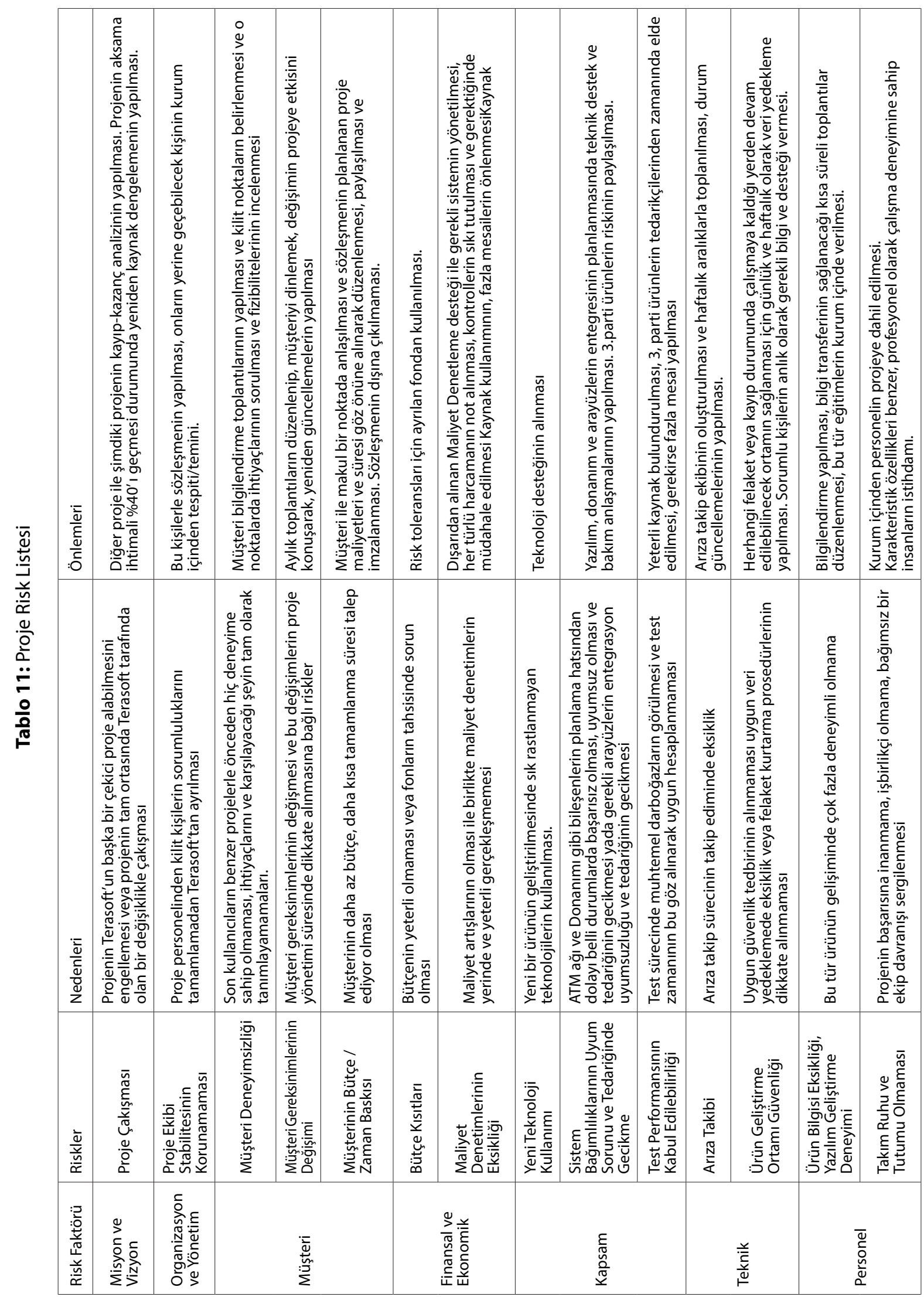




\subsection{Proje Risklerinin Hesaplanması}

Daha sonrasında ise, risklerin proje esnasında gerçekleşme olasılığı, gerçekleştiği zaman projeye olan süre ve maliyet etkisi ve riskin hesaplanan derecesi Tablo 12'de gibi belirlenmiştir.

Tablo 12: Proje Risklerinin Maliyete Etkisine Göre Analiz Sonucu

\begin{tabular}{|c|c|c|c|c|c|}
\hline Riskler & $\begin{array}{l}\text { Gerçeklessme } \\
\text { Olasılığı }\end{array}$ & $\begin{array}{l}\text { Maliyete } \\
\text { Etkisi }\end{array}$ & $\begin{array}{l}\text { Maliyete Göre Risk } \\
\text { Derecesi }\end{array}$ & Süreye Etkisi & $\begin{array}{l}\text { Süreye Göre Risk } \\
\text { Derecesi }\end{array}$ \\
\hline \multirow[t]{2}{*}{ 1. Proje Çakışması } & Küçük & Yüksek & Orta & Orta & Düşük \\
\hline & 2 & 4 & 8 & 3 & 6 \\
\hline \multirow{2}{*}{$\begin{array}{l}\text { 2. Proje Ekibi Stabilitesinin } \\
\text { Korunamaması }\end{array}$} & Küçük & Yüksek & Orta & Orta & Düşük \\
\hline & 2 & 4 & 8 & 3 & 6 \\
\hline \multirow[t]{2}{*}{ 3. Müşteri Deneyimsizliği } & Orta & Orta & Orta & Orta & Orta \\
\hline & 3 & 3 & 9 & 3 & 9 \\
\hline \multirow{2}{*}{$\begin{array}{l}\text { 4. Müşteri Gereksinimlerinin } \\
\text { Değişimi }\end{array}$} & Küçük & Küçük & Düşük & Yüksek & Orta \\
\hline & 2 & 2 & 4 & 4 & 8 \\
\hline \multirow{2}{*}{$\begin{array}{l}\text { 5. Müşterinin Bütçe / Zaman } \\
\text { Baskısı }\end{array}$} & Orta & Orta & Orta & Orta & Orta \\
\hline & 3 & 3 & 9 & 3 & 9 \\
\hline \multirow[t]{2}{*}{ 6. Bütçe Kısıtları } & Orta & Orta & Orta & Yüksek & Orta \\
\hline & 3 & 3 & 9 & 4 & 12 \\
\hline \multirow[t]{2}{*}{ 7. Maliyet Denetimleri Eksikliği } & Orta & Çok Yüksek & Yüksek & Küçük & Düşük \\
\hline & 3 & 5 & 15 & 2 & 6 \\
\hline \multirow[t]{2}{*}{ 8. Yeni Teknolojilerin Kullanımı } & Yüksek & Yüksek & Yüksek & Orta & Orta \\
\hline & 4 & 4 & 16 & 3 & 12 \\
\hline \multirow{2}{*}{$\begin{array}{l}\text { 9. Sistem Bağımlılıklarının Uyum } \\
\text { Sorunu ve Tedariğinde Gecikme }\end{array}$} & Yüksek & Yüksek & Yüksek & Çok Yüksek & Yüksek \\
\hline & 4 & 4 & 16 & 5 & 20 \\
\hline \multirow{2}{*}{$\begin{array}{l}\text { 10. Test Performans Kabul } \\
\text { Edilebilirliği }\end{array}$} & Orta & Orta & Orta & Yüksek & Orta \\
\hline & 3 & 3 & 9 & 4 & 12 \\
\hline \multirow[t]{2}{*}{ 11. Arıza Takibi } & Orta & Orta & Orta & Orta & Orta \\
\hline & 3 & 3 & 9 & 3 & 9 \\
\hline \multirow{2}{*}{$\begin{array}{l}\text { 12. Ürün Geliştirme Ortamı } \\
\text { Güvenliği }\end{array}$} & Yüksek & Yüksek & Yüksek & Yüksek & Yüksek \\
\hline & 4 & 4 & 16 & 4 & 16 \\
\hline \multirow{2}{*}{$\begin{array}{l}\text { 13. Ürün Bilgisi Eksikliği/Yazılım } \\
\text { Geliştirme Deneyimsizliği }\end{array}$} & Yüksek & Orta & Orta & Küçük & Orta \\
\hline & 4 & 3 & 12 & 2 & 8 \\
\hline \multirow[t]{2}{*}{ 14. Takım Ruhu ve Tutumu } & Küçük & Orta & Düşük & Orta & Düşük \\
\hline & 2 & 3 & 6 & 3 & 6 \\
\hline
\end{tabular}

Bu listelenen sonuçlardan süre ve maliyet açısından projeye olan etkisini değerlendirdiğimiz riskler arasından dört adet riskin en yüksek risk grubunda olduğu sonucu ortaya çıkmıştır;

\section{Risk 7: Maliyet Denetimleri Eksikliği}

Risk 8: Yeni Teknolojilerin Kullanımı

Risk 9: Sistem Bağımlılıklarının Uyum Sorunu ve Tedariğinde Gecikme

\section{Risk 12: Ürün Geliştirme Ortamı Güvenliği}

Ancak projenin performans göstergesi olan +/\%10 luk değer daha kesin bilgilere dayalı tahminlere intiyaç duyduğundan risklerin gerçekleşme olasılıkla- rı ve projeye etkileri yeniden değerlendirilmiştir.

Risklere yanıt verme stratejilerini planlamadan önce projenin hangi aktivitelerine olumsuz etkisi olduğu tespit edilmiştir. En yüksek risk grubundaki riskler projenin uygulama ve kurulum ana aktivitelerine etkileri süre ve maliyet açısından nitel ve nicel analiz yöntemleri ile değerlendirilmiştir. Bir ticari proje yazılımı ile detaylı olarak belirlenmiş Uygulama ve Kontrol ana aktivitelerinin tüm detayları; görevler, öncülleri, süreleri, kaynakları (takvim ve maliyet bilgileri), başlama ve tamamlanma tarihleri işlenmiştir. 221,897 TL maliyet ile 1/8/2013 tarihinde başlayıp 3/2/2014 tarihinde bitmesi planlanmıştır. 
Proje risk ekibi ile yapılan nitel risk analizi ile elde edilip sözel ifadeler ile ifade edilen risklerin tehdit olarak kayıtları yapılmıştır. Risklerin olasılık değeri ile süre ve maliyet riskleri en yüksek risk grubunda çıkmıştır Tablo 13.

Tablo13: Nitel Risk analizi

\begin{tabular}{|l|c|c|c|c|c|}
\hline & Olasılık & Çizelge & Maliyet & Performans & Puan \\
\hline Güvenlik & Y & Y & Y & N & 28 \\
\hline Bağımlılık & Y & ÇY & Y & N & 56 \\
\hline $\begin{array}{l}\text { Maliyet } \\
\text { Denetimleri }\end{array}$ & O & D & ÇY & N & 40 \\
\hline Teknoloji & Y & O & Y & N & 28 \\
\hline
\end{tabular}

( Not: Y: yüksek, O: orta, ÇY: çok yüksek, N: Normal, D:düşük)

Olasılık, etki matrisi ve riskler aşağıdaki tablodaki gibi olmuştur Tablo 14.

Tablo 14: Olasılık, Etki Matrisi ve Risklerin Matristeki Yeri

\begin{tabular}{|c|c|c|c|c|c|}
\hline $\begin{array}{c}\text { Olasılık/ } \\
\text { Etki }\end{array}$ & $\begin{array}{c}\text { Çok } \\
\text { Düşük }\end{array}$ & Düşük & Orta & Yüksek & $\begin{array}{c}\text { Çok } \\
\text { Yüksek }\end{array}$ \\
\hline $\begin{array}{c}\text { Çok } \\
\text { Yüksek }\end{array}$ & 6 & 12 & 18 & 36 & 72 \\
\hline Yüksek & 4 & 7 & 14 & 28 & 1-Güvenlik \\
\hline $\begin{array}{c}\text { 4-Teknoloji } \\
\text { Orta }\end{array}$ & 3 & 5 & 10 & $\begin{array}{c}56 \\
\text { l.lığım- }\end{array}$ \\
\hline $\begin{array}{c}\text { Çok } \\
\text { Düşük }\end{array}$ & 1 & 1 & 2 & 4 & $\begin{array}{c}40 \\
\text { 3-Maliyet } \\
\text { Denetim- } \\
\text { leri }\end{array}$ \\
\hline Düs̈ük & 2 & 3 & 6 & 12 & 24 \\
\hline
\end{tabular}

Nitel risk analizinde kullanılan puanlandırma ve risk derecesi hesaplama formülü aşağıdaki gibidir:

Olasılık faktörleri çok düşükten çok yükseğe 1, 3,

5, 7 ve 9 değerlerine sahiptir.

Etki faktörleri çok düşükten çok yükseğe $0.5,1$, 2, 4 ve 8 değerlerine sahiptir.
Risk derecesi $=$ Olasılık faktörü ${ }^{*}$ Etki faktörü

Etki faktörü $=($ süre etki faktörü + maliyet etki faktörü) /2

Şimdi ise sıra, risklerin proje hedefleri üzerindeki belirsizliğinin modellenmesi, modelin proje aktiviteleri üzerindeki iş zaman çizelgesi etkisi ve maliyet tahminleri ile doğrudan ilişkilendirilmesine ve risk derecelerinin hesaplanmasına gelmiştir.

Nicel risk analizi için öncelikle risk analizi yapılarak öncelikle risklerin süre ve maliyet açısından hangi görevleri etkilediği tespit edilmiş, sonra ise riskler ve görevler ilişkilendirilmiştir.

"Güvenlik" riski, projede Risk 12, yazılım geliştirme ortamının güvenliğinin sağlanmaması riskini ifade eder ve \%60 gerçekleşme olasılığı ile süre ve maliyet açısından etkileyeceği aktivitelerle ilişkilendirmiştir.

"Bağımlıık" riski, projede Risk 9, yazılım geliştirmenin başka sistemlere bağımlı olup, uyumsuzluk veya zamanında tedarik edememe riskini ifade eder ve $\% 60$ gerçekleşme olasılığı ile süre ve maliyet açısından etkileyeceği aktivitelerle ilişkilendirilmiştir.

"Maliyet Denetimleri" riski, projede Risk 7, proje süresince maliyet açısından gerekli tedbirlerin alınmaması, yüksek harcamaların gerçekleşme riskini ifade eder ve $\% 40$ gerçekleşme olasılığı ile süre ve maliyet açısından etkileyeceği aktivitelerle ilişkilendirilmiş̧ir.

"Teknoloji" riski, projede Risk 8, proje süresince kullanılacak teknolojilerin yeni olması, pahalı olması, alışık olmama riskini ifade eder ve $\% 60$ gerçekleşme olasılığı ile süre ve maliyet açısından etkileyeceği aktivitelerle ilişkilendirilmiştir.

Monte Carlo benzetim modeli kullanılarak, risk kaydı ve aktivite ilişkilendirme ile risk modeli meydana gelmiştir. Her bir görevi etkileyen risklerin etki ve gerçekleşme olasılıklarını hesaplamak mümkündür. Burada ise yalnızca uygulama ve kurulum dağılım grafiği verilmiştir Şekil 2. 


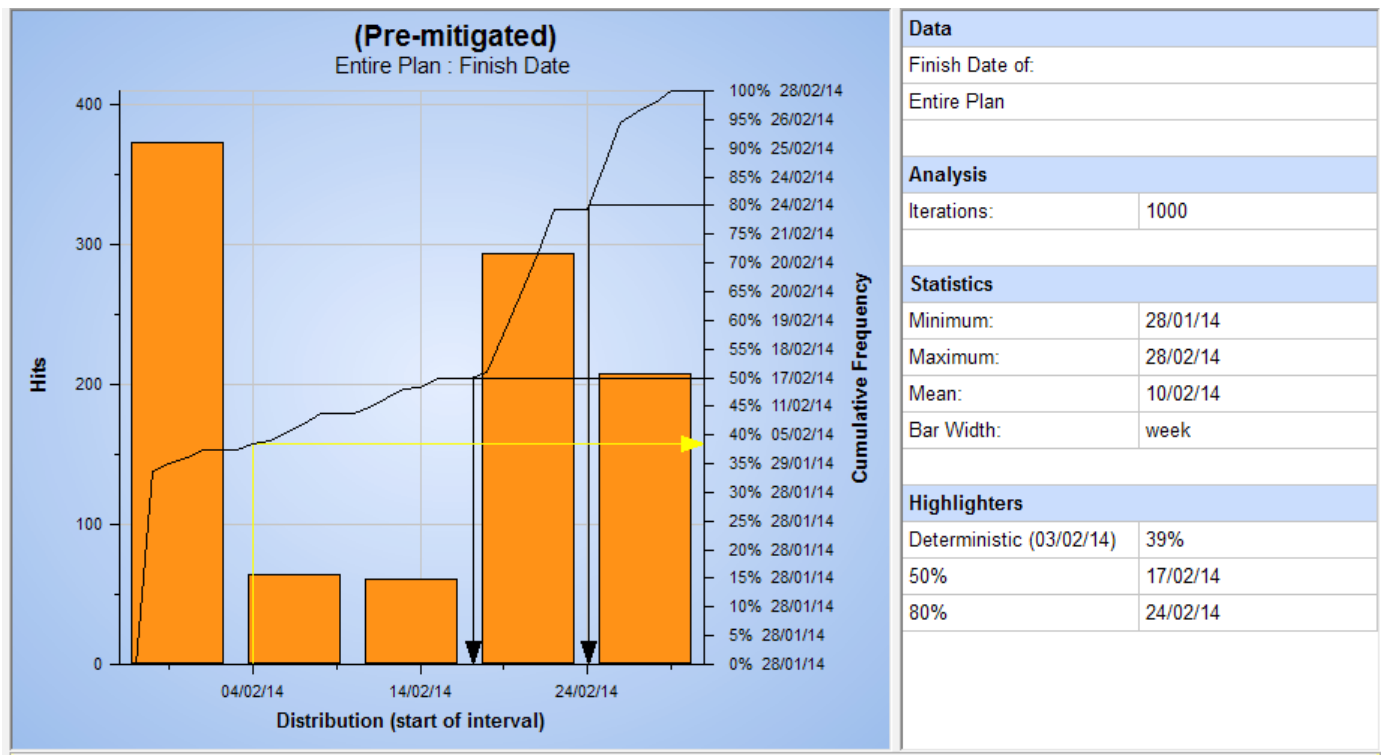

Şekil 2: Uygulama, Kurulum ve Bitiş Zaman Dağılım Grafiği

Dağılım grafiği değerlendirildiğinde, ana aktivitenin tanımlanan en yüksek risklerin etkisiyle \% 39 ihtimal ile planlanan tarih 3/2/2014 biteceği görülmektedir. En erken bitiş tarihi 28/1/2014, en geç bitiş tarihi 28/2/2014 olabileceği görülmektedir. Bu da projenin 25 iş günü ötelenme riski taşıdığı bununda belirlenen \%10 'luk sapma değerini aşabileceği anlaşılmaktadır.
Aynı hesaplamayı \%80 ile yaptığımızda, bitiş tarihi 24/2/2014, \%50 intimal ile 17/2/2014 olacaktır. Projedeki uygulama ve kontrol aktivitesinin maliyetlere nasıl etki ettiği incelendiğinde ise aşağıdaki gibi sonuç elde edilmiştir Şekil 3. Bu sonuca göre maliyet değeri en düşük 221,897 TL, en yüksek 260,892 TL olacaktır.

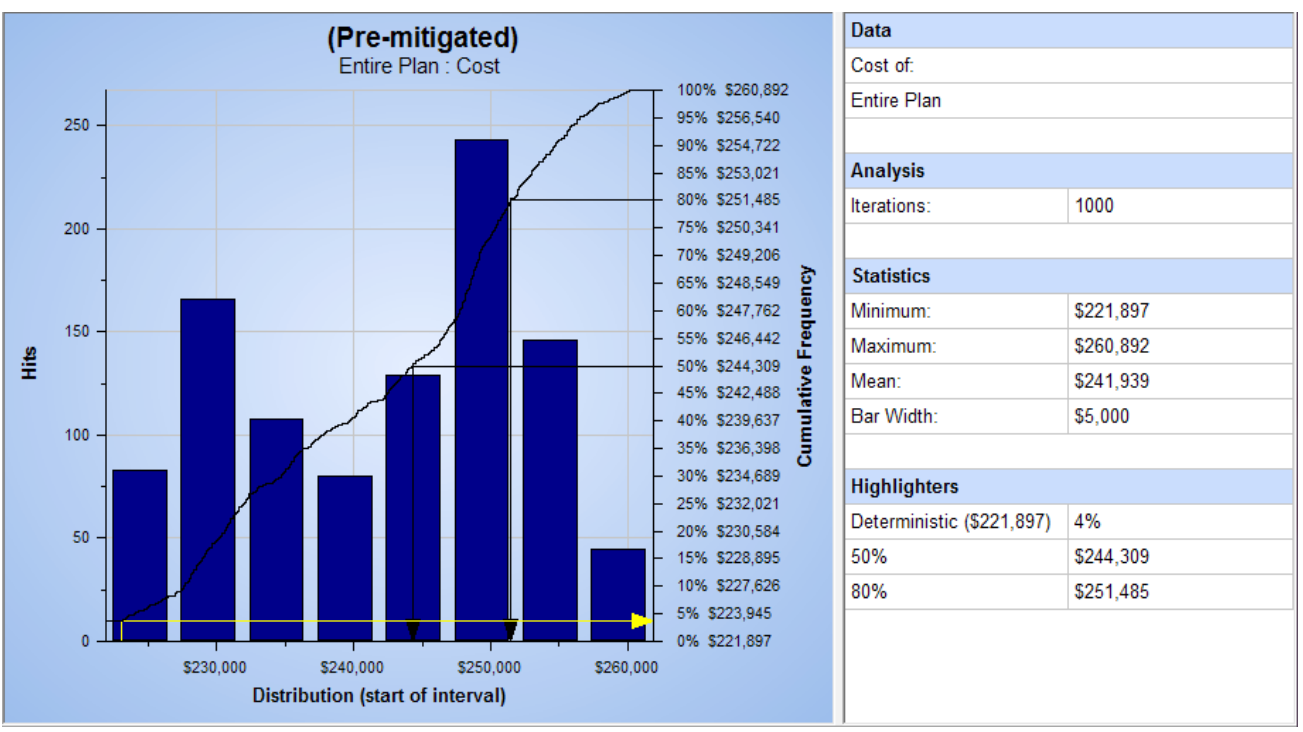

Şekil 3: Proje Maliyeti Dağılım Grafiği

Kesin (deterministik) değerler dikkate alındığında planlanan maliyete göre aktivitenin yaklaşık \% 4 ihtimal ile gerçekleşeceği belirlenmiştir. Buradan aktivitenin 38.995 TL bir artış ile bitme riski mevcut olduğu görülmüştür. Planlanan maliyetin yaklaşık \%18'ine tekabül etmekte bu planlama aşamasında kabul edi- len \%10'luk sapmayı geçtiği görülmektedir. Şekil 4'de farklı intimallere göre oluşabilecek bitirilme maliyetleri görülmektedir. Bu sonuçlara göre örneğin, proje maliyeti \%80 intimal ile 251,485 TL, \%50 intimal ile 244309 TL olması beklenmektedir. 


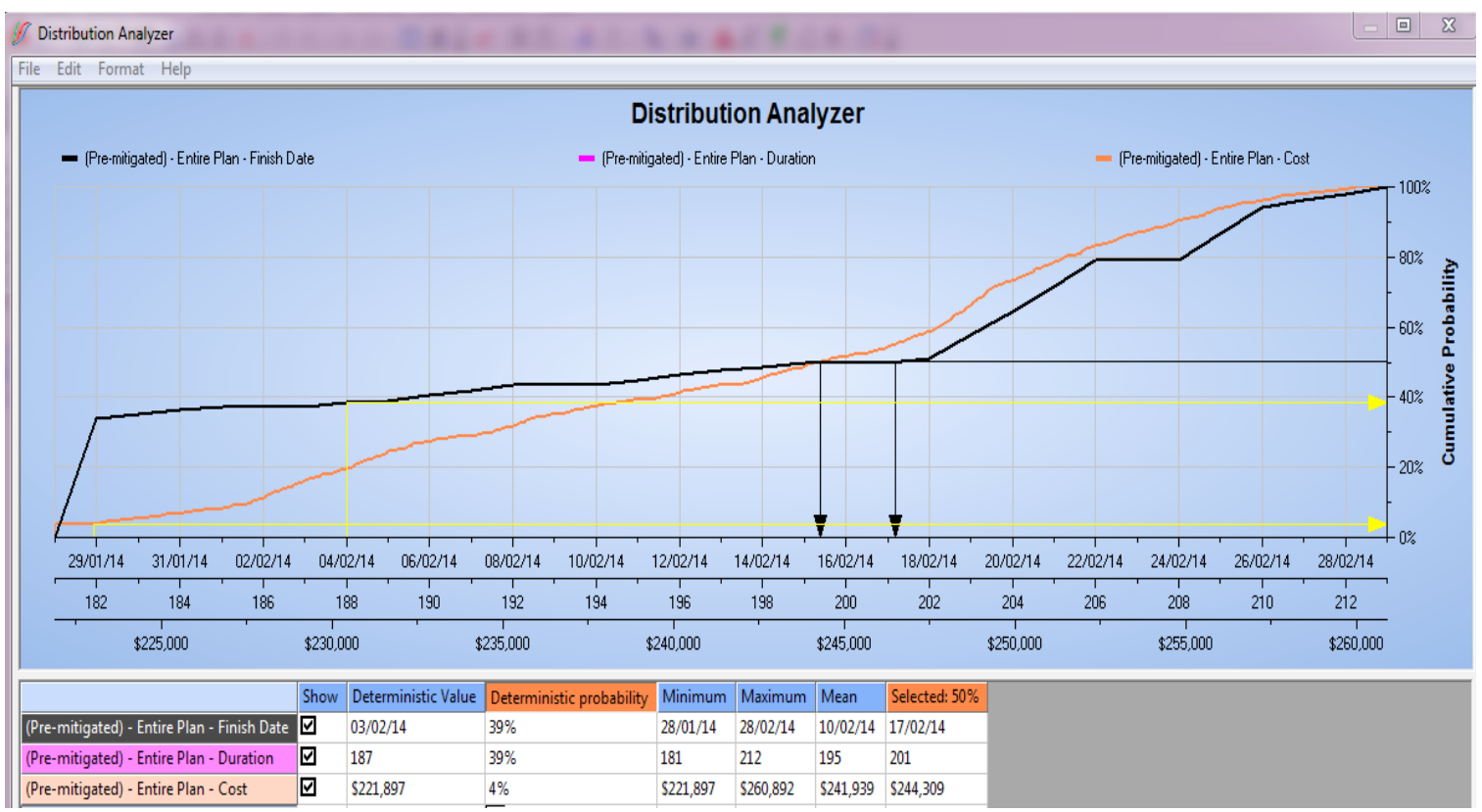

Şekil 4: Proje Süresi, Maliyeti ve Bitiş Tarihi Dağılım Analizi

\subsection{Risklere Yanıt Verme Stratejisi}

Risklere karşı alınabilecek risk yanıt verme stratejilerinin belirlenmesi ve kaydının yapılmasında ise, risk stratejileri belirlenirken her bir alternatifin öncelikle risk derecesi, ekonomik olması, zamanlama dikkate alınarak kullanılacak kaynaklar analiz edilmiştir. Her bir risk için risk yanıtlama stratejisi belirlenmiştir. Projeyi etkileyecek yüksek dereceli 4 risk güvenlik, bağımlılık, maliyet denetimleri ve teknolojik olarak belirlenmiştir. Geliştirme ortamı güvenliği riski için riskten kaçınma stratejisi izlenmiştir. Gerekli risk önleme faaliyetleri uygulamaya alınmış ve risk önleme maliyetine katlanılmış ve alınan risk önleme faaliyeti veri yedekleme çalışmasının maliyeti ise $2400 \mathrm{TL}$ olmuştur. Sistem bağımlıığının uyum sorunu ve tedariğinde gecikme riski için riski transfer etme stratejisi izlenmiş ve diğer sistemlerin tedarikçileri ile bir sözleşme imzalanarak bu riski gerçekleşmesi durumunda sorumluluğun firmadan olmayacağına soncuna varılmış bunun önlenme çalışması maliyeti ise $2000 \mathrm{TL}$ olmuştur. Maliyet denetimlerinin eksikliğinden dolayı artan maliyetler riski için azaltma stratejisi izlenmiştir gerekli önleme çalışmaları yapılarak proje esnasında takip edilip uygulamaya geçilmiş bunun maliyeti de 1200 TL olmuştur. Yeni teknolojilerin kullanımının riski için azaltma stratejisi izlenerek, teknolojik desteğin alımı ile bu riski önlenmeye çalışılmıştır. Proje uygulama esnasında izlenerek gerektiği anda önleme faaliyeti uygulamaya konulmuştur. Bunun maliyeti projeye ek olarak 1200 TL dir. Tablo 15. Toplam risk yanıtlama maliyeti 8400 TL'dır ve risk için ayrılan fondan karşılanabilecektir.

Tablo 15: Riske Yanıt Verme Stratejisi ve Uygulama Maliyeti

\begin{tabular}{|c|c|c|c|c|c|c|c|c|}
\hline \multicolumn{6}{|c|}{ Riskler } & \multicolumn{3}{|c|}{ Riskin Önlenmesi } \\
\hline & Olasılık & Çizelge & Maliyet & Performans & Puan & Karar & Oluşturulan Cevap & Maliyet \\
\hline Güvenlik & $\mathrm{Y}$ & $\mathrm{Y}$ & $\mathrm{Y}$ & $\mathrm{N}$ & 28 & Kaçınma & Veri yedekleme & 2400 \\
\hline Bağımlılık & Y & ÇY & Y & $\mathrm{N}$ & 56 & Transfer & Teknik destek/bakım servisi & 2000 \\
\hline M. Denetim & $\mathrm{O}$ & D & ÇY & $\mathrm{N}$ & 40 & Azaltma & İlgili birim desteği & 1200 \\
\hline Teknoloji & Y & 0 & Y & $\mathrm{N}$ & 28 & Azaltma & Teknoloji destek birimi & 1200 \\
\hline
\end{tabular}

( Not: Y: yüksek, O: orta, ÇY: çok yüksek, N: Normal, D:düşük)

Bu risklerin projeye etkileri ise aşağıdaki gibi olmuştur Tablo 16. 
Tablo 16: Risk Yanıt Verildikten Sonra Projeye Etkisi

\begin{tabular}{|l|l|c|c|c|c|c|c|}
\hline \multicolumn{3}{|c|}{ Oluşturulan Karar } & \multicolumn{5}{c|}{ Alınan Karar sonrası } \\
\hline Karar & \multicolumn{1}{|c|}{ Oluşturulan Cevap } & Maliyet & Olasılık & Çizelge & Maliyet & Performans & Puan \\
\hline Kaçınma & Veri yedekleme & 2400 & $\mathrm{~N}$ & $\mathrm{~N}$ & $\mathrm{~N}$ & $\mathrm{~N}$ & 0 \\
\hline Transfer & Teknik destek/bakım servisi & 2000 & $\mathrm{D}$ & $\mathrm{D}$ & $\mathrm{D}$ & $\mathrm{N}$ & 3 \\
\hline Azaltma & İlgili birim desteği & 1200 & ÇD & ÇD & $\mathrm{D}$ & $\mathrm{N}$ & 1 \\
\hline Azaltma & Teknoloji destek birimi & 1200 & $\mathrm{D}$ & ÇD & $\mathrm{O}$ & $\mathrm{N}$ & 6 \\
\hline
\end{tabular}

Risk yanıt verme stratejilerinin uygulamaya alındıktan sonraki risk değerlendirmesini görmek, model oluşturmak ve projenin üzerindeki etkinin aktiviteler ile ilişkilendirilerek tahmin edilmesi maksadıyla riskler için yanıt verme stratejileri uygulandıktan sonra projeye etkilerinin ilişkili aktivitelerin üzerinde nasıl olacağı incelenmiştir. Yapılan benzetim modeline göre risk analizi yapıldığında, deterministik olarak belirle-

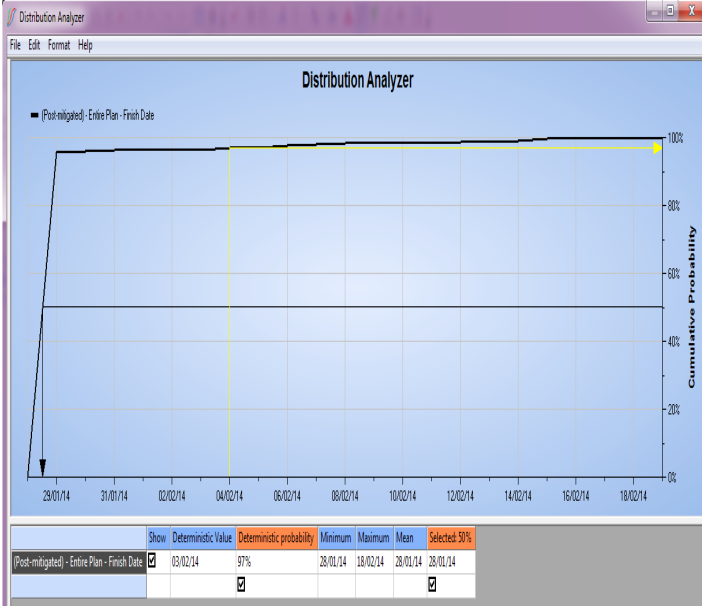

Proje Bitiş Tarihi Dağılım Grafiği nen tamamlanma tarihi olan 3/2/2014'ü görme \%97 ihtimale sahip olduğu görülmüştür. En erken tamamlanma tarihi 28/01/2012 ve en geç tamamlanma tarihi 18/02/2014 olarak bulunacaktır. Buradan projenin 15 günlük bir gecikme riskine sahip olduğunu göstermektedir. Bu değer belirlenmiş \%10'luk sapma değeri altında olduğundan kabul edilebilir sınırlar içinde kalmıştır.

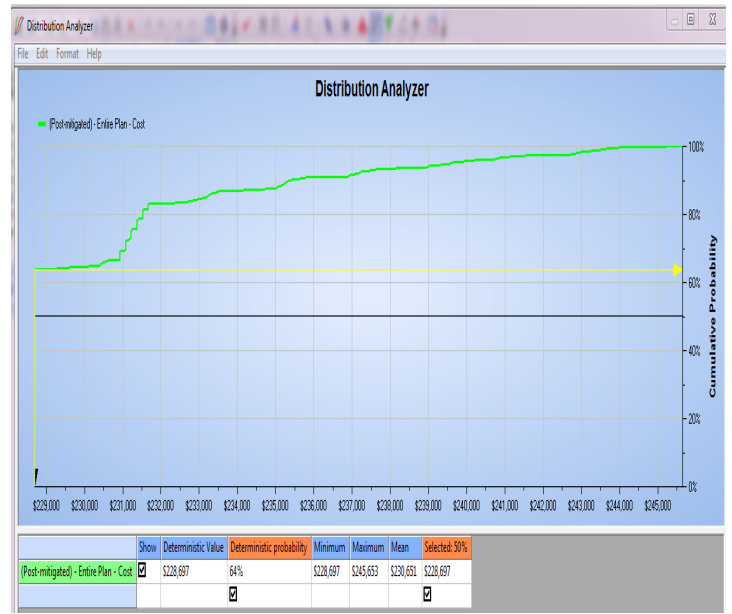

Proje Maliyet Dağılım Grafiği

Şekil 5: Proje bitiş ve maliyet dağılımı

Deterministik olarak belirlenen toplam maliyet en az 228,697 TL ve en yüksek 230,651 TL olabilecektir. Toplamda projenin 8754 TL'ık bir maliyet riskine sahip olduğu görülmüştür. Risk yanıtlama stratejilerinin maliyeti de bunun içindedir $(228,697-221,897=6800)$. Yani projemizi planlanan ana aktivite maliyetini geçmeden bitirebileceğiz ve ek maliyetler\%10'luk sapma içinde olduğu için ayrılan fondan kullanılabilecektir Şekil 5.

Risk sorumluları tarafından her bir risk proje süresince izlenmekte ve kayıt altına alınmaktadır. Bu izleme sürecinde proje hedeflerinden maliyet ve sürenin planlananı aşıp aşmadığı kontrol edilmektedir. Bu kontroller risk yönetiminin bir parçası olup aylık olarak risk sorumluları tarafından yapılmaktadır. Kontrol sürecinde proje hedeflerinden en az birinde sapma olduğu görüldüğünde, buna sebep olacak durumların analizi açısından riskler tekrar gözden geçirilmesi daha uygun olacaktır.
Risk yönetim süreci değerlendirme sürecinde ise, bu proje için 145.000 TL'e kadar ek maliyet ve 26 güne kadar da ek süre tanınacağına karar verilmiştir. Bu değerler projenin varsayımlarında söylenen projenin +\%10 ile -\%10 olarak tamamlanma olasılığına istinaden toplam maliyetin $\% 10$ ve toplam tamamlanma süresinin \%10'una tekabül etmektedir. Proje esnasında ihtiyaç duyulduğunda da bu fonun kullanılması uygun olacaktır. Proje başlamadan önce planlama aşamasında belirlenen risk yanıtlama stratejileri projenin beklenen performansını gösterme yüzdesi olan \%10'luk dilimi karşılayacak şekilde ayarlanmıştır. Ek maliyet ve zaman değerleri projenin hesaplanan maliyetinin ve tamamlanma süresinin üstüne eklenerek projenin son durum tamamlanma süresi ve maliyeti belirlenmiş olacaktır. 


\section{SONUÇLAR}

Bu çalışmada, yazılım geliştirme projesine ait risk analizi ve yönetimi için seçilecek yöntemin belirlenmesi için bir yaklaşım önerilmiştir. Önerilen yöntem örnek bir vaka ile sınanarak elde edilen sonuçlar tartışılmıştır.

Mevcut proje yönetimi sisteminin analizinden sonra, kullanılmakta olan proje yönetimi sürecinin parçaları olarak proje sonrası analiz ve risk yönetimi süreçleri tasarlanmış ve mevcut proje yönetimi sürecine dahil edilmiştir. Hem proje sonrası analiz hem de risk yönetimi süreçleri örtük bilginin açık ve yazılı bilgiye dönüştürülmesinde yararlı olmuştur. Bu olanaktan yararlanmak için bir bilgi tabanı tasarlanmış ve uygulamaya konulmuştur.

Proje sonrası analizlerin büyük bir kısmını risk ile ilişkili konuların oluşturduğu görülmüştür. Diğer taraftan, risk yönetimi bir dizi proje sonunda kazanılan ve proje sonrası analizler yoluyla açık hale dönüşen deneyime dayandığı görülmüştür. Risk yönetimi ve proje sonrası analiz süreçleri birbiriyle yakın bir etkileşim içindedir. Her ikisi de proje yönetim kalitesini geliştirerek projenin başarısını arttırmayı hedefler. Bu nedenle risk yönetimi ve proje sonrası analiz süreçleri birbirleriyle yoğun bilgi alışverişi içinde bulunacak şekilde tasarlanmıştır.

Projeler için belirsizlik ortamının doğuracağı olumsuz sonuçlar, yani hedefe ulaşmada tehdit niteliğinde olan riskler, projeyi başarılı olarak gösterecek planlanan hedefler üzerinde olumsuz etki meydana getireceği için risk yönetimi süreçlerini uygulama bu risklerin belirlenip, proje hedeflerini ne derece etkilediğini analiz etme ve bu olumsuz etkiyi önlemek amaçlı alınabilecek tedbirleri planlama ve onları izleme açısından önem ve gereklilik gösterir. Diğer bir deyişle proje yönetilirken, planlanan ile gerçekleşenin arasındaki olumsuz farkın en aza indirgenmesi veya sıfırlanması bu yönetim alanının planlanması, uygulanması ve izlenmesinin mutlak sonucu olarak görülür.

Risk yönetimi projenin kalite, zaman, maliyet ve kapsam açısından hedeflerine en az kayıpla ulaştırabilecek adımlara sahiptir.

Risk yönetiminin birbirini takip eden aşamalarının proje boyunca süreklilik gösterdiği ve tekrarlanabilir olduğu tespit edilmiştir. Bunun önemi ise, özellikle izleme ve kontrol aşamalarının etkinliğini ikincil risklerin belirlenmesi ve onların önlenmesinde ortaya çıkmıştır.

Planlama aşamasında belirlenen sorumlulukların ve rollerin benzer görevlerde veya projelerde yer almış kişilere atanması riskleri tanımlama ve analizinde önemli görüşlerin elde edilmesini sağlamıştır.

Aktivitelerde karşılaşılması muhtemel riskler her aktivite için farklılık göstermektedir. Bu nedenle risk belirleme aşamasında risklerin sınıflandırılması gerektiğinin önemi ortaya çıkmıştır. Sınıflandırma risklerin aktiviteye olan etkilerinin değerlendirilmesi açısından daha etkin olmuştur.

Risklerin analizini yaparken birçok teknik ve yöntemin kullanabileceği ama çoğunlukla sayısal metotların takip edilmesinin daha doğru karar verme açısından tercih edilmesi gerektiği görülmektedir.

Toplam projeye etkisi düşük olan bazı aktiviteler içindeki bir riskin, olasılık etki tablosunda risk puanı büyük olmasına rağmen toplam projeye olan etkisi düşük olabileceğinden (veya tam tersi), proje aktivitelerinin her birinde olabilecek riskler ve bu risklerin olasılık ve etkileri proje hedefleri açısından ayrı olarak değerlendirilmiştir. Proje hedeflerinden maliyet ve süre üzerinden hesaplamaların yapılmış olması ile projenin daha sayısal olarak değerlendirilmesi sağlanmıştır.

Risk analizinden sonra yüksek dereceli risk olarak değerlendirilen riskler için risk yanıtlama stratejisi fayda zarar analizi dikkate alınarak belirlenmiş, uygulanmıştır. Risk yönetim giderleri projenin bütçesine yansıtılmış olup; risk yönetiminin projenin planlama aşamasında yapılması bütçenin daha doğru hesaplanmasına yardımcı olmuştur.

Riskler için belirlenen stratejiler proje esnasında izlenerek, uyarı mekanizmasının yardımı ile risk kayıt deposundaki son durum risk derecesinin değişimi görülebilir ve proje sonrası gereken müdahaleyi yapma fırsatı elde edilir. Proje boyunca meydana gelebilecek olumsuz sonuçlarda izlenir ve risk haline gelmeden önlemi alınabilmektedir. Bu da olası risklerin maliyeti için bir bütçe ayrılması gerektiğini gösterir. Bu doğrultuda yapılan her çalışma projeyi olumlu yönde etkilemekte, mümkünse riskler oluşmadan önlenmesi sağlanabilecektir. 


\section{KAYNAKLAR}

Anantatmula, V. ve Fan, Y. (2013) "Risk Management Instruments, Strategies and Their Impact on Project Success" International Journal of Risk and Contingency Management 2(2): 27-41.

Bannerman, P.L. (2008) "Risk and Risk Management in Software Projects: A Reassessment" Journal of Systems and Software, 81(12):2118-2133.

Barry, W.B. (1991) "Software Risk Management: Principles And Practices” Software, IEEE , 8(1):32-41.

Barry W.B. ve DeMarco, T. (1997) "The Atlantic Systems Guild, Software Risk, Management" IEEE Software, 17-19.

Ceylan, H. ve Başhelvacı, V.S. (2011) "Risk Değerlendirme Tablosu Yöntemi ile Risk Analizi: Bir Uygulama" International Journal of Engineering Research and Development, 3(2): 25-33.

Dikmen, I., Birgonul, M.T., Anac, C., Tah, J.H.M. ve Aouad, G. (2008) "Learning From Risks, A Tool For Post-Project Risk Assessment" Automation in Construction, 18(1):42-50.

Drucker, P.F. (1996) Yönetim Uygulaması, İstanbul, İnkilap Kitabevi.

Emhan, A. (2009) "Risk Yönetim Süreci Ve Risk Yönetmekte Kullanılan Teknikler" Atatürk Üniversitesi İktisadi ve İdari Bilimler Dergisi, 23(3):209-220.

Erdem, O.A. ve Younis, A.E. (2014) "Yazılım Projelerinin Geliştirme Sürecinde Yönetim” Bilişim Teknolojileri Dergisi, 7(1):1-9.

Kwak, Y.H. ve Stoddard, J. (2004) "Project Risk Management: Lessons Learned From Software Development Environment" Technovation, 24(11): 915-920.

McManus, J. (2004) Risk Management in Software Development Projects, Elsevier, Butterworth-Heinemann.

Nakatsu, R.T. ve Iacovou, C.L. (2009) "A Comparative Study of Important Risk Factors Involved in Offshore and Domestic Outsourcing of Software Development Projects: A Two-Panel Delphi Study" Information and Management, 46(1):57-68.
Narayanaswamy, R., Grover,V. ve Henry, R.M. (2013) "The Impact of Influence Tactics in Information System Development Projects: A Control-Loss Perspective" Journal of Management Information Systems, 30:191-226.

Ropponen, J. ve Lyytinen, K. (2000) "Components Of Software Development Risk: How To Address Them? A Project Manager Survey" IEEE Transactions on Software Engineering, 26(2):98-112.

Schmidt, R., Lyytinen, K. ve Keil, M. ve Cule, P. (2001) "Identifying Software Project Risks: An International Delphi Study" Journal of Management Information Systems, 17: 5-36.

Sönmez, E. (2007) "Neden Proje Yönetimi” Yüksek Lisans Tezi, İstanbul, Mimar Sinan Güzel Sanatlar Üniversitesi Fen Bilimleri Enstitüsü.

Ulusoy, G., Fayda, A.S.N. ve Meydanl, İ.İ. (2012) "Ar-Ge Projeleri için Proje Sonrası Analiz ve Risk Yönetimi Süreçleri” Atilla, Ö.M. (ed.) Teknik Değişimin Ekonomisi ve Yönetimi, İstanbul, Pan Yayıncllık.

Uzzafer, M. (2013) "A Contingency Estimation Model For Software Projects" International Journal of Project Management, 31(7): 981-993.

Uzuntaş, F. (2010) "Proje Yönetiminde Risk Analizi" Yüksek Lisans Tezi, İstanbul, İstanbul Üniversitesi Sosyal Bilimler Enstitüsü.

Verner, J.V. ve Evanco, W.M. (2005) "In-House Software Development: What Project Management Practices Lead To Success?" IEEE Software, 22(1): 86-93

Vorster, A. ve Labuschagne, L. (2005) A Framework For Comparing Different Information Security Risk Analysis Methodologies, Proceedings of the 2005 annual research conference of the SAICSIT '05.

Yacov Y.H. (2009) Risk Modeling, Assessment, and Management, John Wiley \& Sons. 
